\title{
VPLYV ASYMETRICKÉHO USPORIADANIA INKLÚZIÍ V BETÓNOVÝCH TELESÁCH NAMÁHANÝCH OSOVÝM TLAKOM
}

\author{
THE EFFECT OF ASYMMETRICAL INCLUSION ARRANGEMENT ON \\ CONCRETE SPECIMENS SUBJECTED TO UNIAXIAL COMPRESSION
}

\author{
Maroš Kováč ${ }^{* 1}$, Peter Sabol $^{1}$
}

${ }^{*}$ maros.kovac@tuke.sk

${ }^{1}$ Technická univerzita v Košiciach, Letná 9, 04200 Košice

\begin{abstract}
Abstrakt
Betón je charakteristický rôznorodost’ou svojho zloženia - heterogenitou. Predpokladá sa, že heterogénna povaha betónu, v ktorej prevládajú vel'ké zrná kameniva, riadi proces šírenia trhlín v betóne. V prípade obyčajného betónu pôsobia vel'ké zrná kameniva ako významné koncentrátory napätia, ktoré usmerňujú priebeh silového toku a ovplyvňujú tak mechanické vlastnosti betónu. Ciel'om výskumu bolo analyzovat' vplyv početnosti vel'kých zín kameniva (inklúzií) pri ich asymetrickom usporiadaní na sérií skúšobných vzoriek o troch rôznych vel'kostiach. Pozornost' bola venovaná úrovni dosiahnutého medzného napätia skúšobných vzoriek, ktoré boli namáhané osovým tlakom.
\end{abstract}

Klíčová slova

Obyčajný betón, osový tlak, inklúzia, matrica

\begin{abstract}
Concrete is characterized by the diversity of its composition - heterogeneity. It is considered that the heterogeneous nature of concrete, in which coarse aggregate grains dominate, controls the process of crack propagation in concrete. In the case of normal concrete, coarse aggregate grains act as the significant stress concentrators, which determine the course of the force flow and thus influence the mechanical properties of the concrete. The aim of the research was to analyse the effect of the number of coarse aggregate grains (inclusions) in their asymmetrical arrangement on a series of test specimens of three different sizes. Attention was paid to the level of the ultimate stress value achieved by the specimens' failure under uniaxial compression.
\end{abstract}

\section{Key words}

Normal concrete, uniaxial compression, inclusion, matrix

\section{1 ÚVOD}

Ciel’om tohto experimentálneho výskumu bolo preskúmat', či rôzny počet inklúzií v skúšobnej vzorke ovplyvňuje dosahovanú normovanú pevnost' telies pri ich asymetrickom usporiadaní vzhl'adom na smer pôsobenia zat'aženia. Výslednú normovanú pevnost' skúšobných vzoriek nemusí ovplyvňovat' iba počet inklúzií, ale aj typ materiálu inklúzie a kvalita rozhrania inklúzie a cementovej matrice - poloha, počet a vel'kost' rozhraní. Tieto vstupné premenné parametre môžu ovplyvňovat' dosahovanú normovanú pevnost' skúšobných vzoriek a tvar krivky $\sigma-\varepsilon$. Pozornost' bola venovaná výberu vhodného normovacieho parametra, ktorý zohl'adní rozdielnu kvalitu betónových skúšobných vzoriek. Analýza výsledkov teda bola vykonaná na normovanej pevnosti vzoriek prostredníctvom vhodného normovacieho parametra.

V príspevku sú prezentované čiastočne výsledky výskumu, ktorý pozostával zo 6 sérií experimentálnych skúšok. Každá séria pozostávala z 18 skúšobných vzoriek, kde sa menil počet inklúzií od 1 do 5 , pričom súbor vzoriek obsahoval jednu vzorku bez inklúzie. Na prípravu vzoriek bola použitá suchá betónová zmes triedy C16/20. Testovacie vzorky sa odliali do ocel'ovej formy, kde boli predtým nalepené inklúzie v požadovanej polohe. Súčasne boli vybetónované vzorky pre stanovenie materiálových vlastností betónovej matrice. Pevnostné charakteristiky betónu sa zist'ovali v 7. deň od betonáže. 
V širšom experimentálnom výskume boli použité dva druhy rozhrania - bola vytvorená dvojaká súdržnost' ocel'ových inklúzií v tvare valčekov a betónovej matrice. Tento článok sa zameriava na prezentáciu vybraných výsledkov na skúšobných vzorkách, kde bolo použité rozhranie typu $(S)$ - ocel'ová inklúzia/betónová matrica pri asymetrickom usporiadaní inklúzií vzhl'adom na smer pôsobenia zat'aženia.

Výška ocel’ových inklúzií bola identická s híbkou skúšobných vzoriek t. j. $50 \mathrm{~mm}$. Pomer strany skúšobnej vzorky a priemeru inklúzie (pomer $h / \phi$ ) bol konštantný o hodnote 5. Priemer inklúzií bol 40, 30 a 20 mm. Skúšky v osovom tlaku boli vykonané na skúšobných vzorkách troch rôznych vel'kostí, kde sa menila štíhlost' (pomer $h / d$ ) skúšobných vzoriek:

- $200 \times 200 \times 50 \mathrm{~mm}, h / d=4,0, \phi=40 \mathrm{~mm}$,

- $150 \times 150 \times 50 \mathrm{~mm}, h / d=3,0, \phi=30 \mathrm{~mm}$,

- $100 \times 100 \times 50 \mathrm{~mm}, h / d=2,0, \phi=20 \mathrm{~mm}$.

\section{POPIS SÚČASNÉHO STAVU}

V betónových konštrukciách identifikujeme deformačné polia uzlov s pôsobiacim sústredeným namáhaním, ktoré sú sprevádzané zmenou hustoty a tvaru silových trajektórií. Tieto zmeny sú spôsobené prítomnost'ou vel'kých zín kameniva a/alebo výstužných prútov (inklúzií) v betóne, zhlukov zín bežnej vel'kosti, alebo prítomnost’ou kaverny v okolí zrna kameniva. Tieto vnútorné imperfekcie patria medzi dôležité parametre, ktoré ovplyvňujú proces porušovania betónových skúšobných telies, a teda aj iniciáciu a rozvoj trhlín v betóne a môžu mat' negatívny vplyv na odolnost' betónových prvkov [1].

Vzájomne usporiadanie inklúzií v betónovej matrici usmerňuje priebeh silového toku, pričom slabé spojenie medzi inklúziou a matricou vedie k iniciácii trhliny na ich rozhraní. Rozhrania zín a cementovej matrice sú teda, na jednej strane, prekážkami šírenia trhlín, ale na strane druhej, sú súčasne aj zdrojom ich iniciácie [2].

Zistilo sa, že zmena zakrivenia tlakových trajektórii spôsobí lokálny priečny t’ah a zmena hustoty trajektórii spôsobí miestne zvýšenie tlaku, teda stlačenie. Zároveň sa zistilo, že šmykové napätie sa rozvíja vo vrchole inklúzie a v spodnej časti inklúzie. V týchto oblastiach, ktoré majú približne tvar kužel’ov vzniká priestorový tlak, čo spôsobí, že matrica v týchto oblastiach nezlyhá [3].

Okrem vyššie uvedených parametrov ovplyvňujúcich pevnost’ betónu sa z predchádzajúcich výskumov zistilo, že odlišný materiál inklúzie, ako aj pomer tuhosti relatívne mäkkej matrice a tuhej inklúzie významne interferoval proces porušovania skúšobných vzoriek [4]. Zároveň sa zistilo, že vzájomná vzdialenost' inklúzií ovplyvňovala proces porušovania skúšobných vzoriek, pričom odolnost' vzoriek klesala s rastúcim počtom inklúzií [5].

\section{METODIKA}

\section{Usporiadanie skúšky a materiál vzoriek}

Skúšky boli vykonané pomocou zat'ažovacieho zariadenia pozostávajúceho z tuhých ocel'ových platní, závitových tyčí a hydraulického zdviháka (Obr. 1). Použitím tuhých ocel'ových platní bolo vytvorené vysoké trecie napätie na kontaktnej ploche zat’ažovacieho zariadenia a skúšobného telesa. Takéto usporiadanie skúšky zabránilo priečnej deformácií na podstavách ocel'ových platní, v dôsledku čoho nastal vznik ovinutých oblastí. Tieto oblasti sa vyznačujú pôsobením priestorového tlakového napätia. Betónová matrica sa v týchto oblastiach neporuší, pričom vznikajú oblasti bez trhlín, ktoré sa podobajú tvaru kužel'ov [3].

Skúšobné vzorky boli počas experimentu vystavené osovému tlaku. Skúšky boli riadené silou so zat'ažovacím krokom približne 9,32 kN. V priebehu skúšky bolo zaznamenané zvislé stlačenie vzorky a presné hodnoty zat’aženia v zat'ažovacích krokoch. Zvislá deformácia sa odčítavala pomocou dvoch indikátorových meradiel s presnost'ou 0,001 mm. Na Obr. 1 je znázornená skúšobná vzorka SQ-7-200-40-S-17 po jej porušení z jej prednej a zadnej strany. Predná čast' vzorky bola natretá vápnom, kde boli neskôr nanesené chaoticky usporiadané čierne bodky za účelom bezkontaktného merania deformácie fotogrametrickým systémom GOM Aramis. Využitie metódy fotogrametrie pri tlakových skúškach umožnilo získat’ informácie o iniciácii, šírení a rozvoji trhlín vo vzorkách. Zo skôr vyhodnotených čiastkových výsledkov výskumu sa zistilo, že iniciácia trhlín nastala na rozhraní inklúzie a betónovej matrice, pričom d'alší nárast zat’aženie spôsobil rozvoj a šírenie trhlín do matrice [6].

Pevnostné charakteristiky betónu boli stanovené na vzorkách s rozmermi $400 \times 100 \times 100 \mathrm{~mm}(h / d=4,0) \mathrm{kde}$ bola skúmaná hranolová pevnost' betónu v tlaku $\left(f_{\mathrm{cm}, \mathrm{pr}}\right)$, pevnost' $\mathrm{v}$ t’ahu pri ohybe $\left(f_{\mathrm{cf}, \mathrm{m}}\right)$ a modul pružnosti betónu $\left(E_{\mathrm{cm}}\right)$. Na vzorkách s rozmermi $100 \times 100 \times 100 \mathrm{~mm}(h / d=1,0)$ boli stanovené hodnoty pevnosti betónu $\mathrm{v}$ priečnom t’ahu $\left(f_{\mathrm{ct}, \mathrm{sp}, \mathrm{m}}\right)$ a kockovej pevnosti betónu v tlaku $\left(f_{\mathrm{cm}, \mathrm{cu}}\right)$. Prehlad' materiálových vlastností betónu prislúchajúci ku konkrétnym vzorkám je uvedený v Tab. 1. 

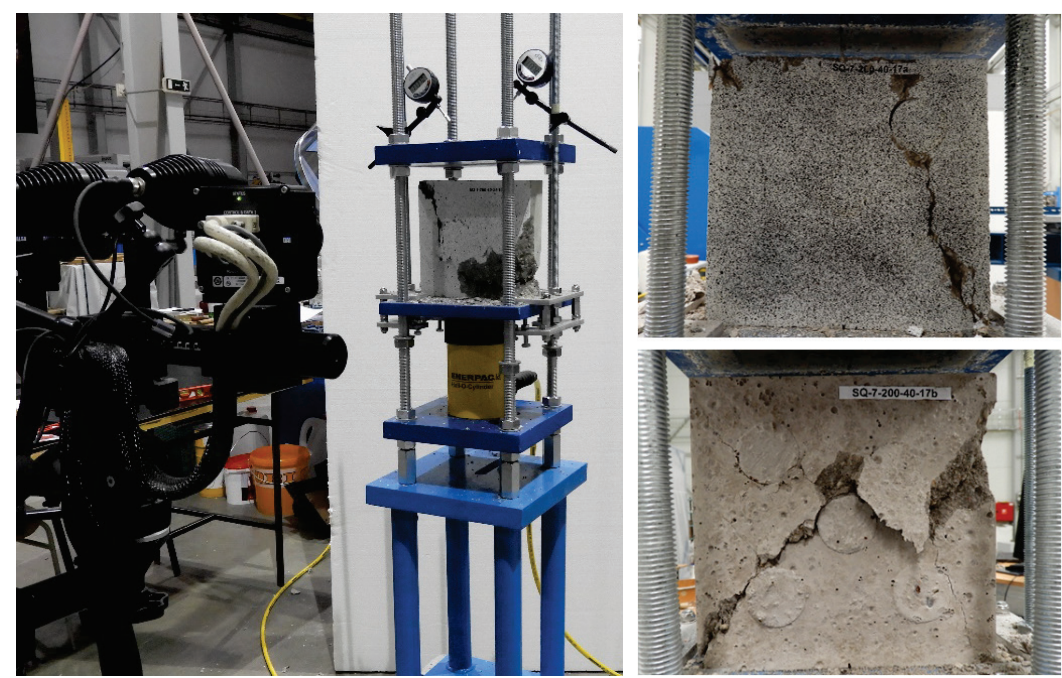

Obr. 1 Usporiadanie skúšky (vl'avo) a skúšobná vzorka po porušení z prednej a zadnej strany (vpravo).

Tab. 1 Materiálové charakteristiky betónu.

\begin{tabular}{|c|c|c|c|c|c|c|}
\hline Skúšobná vzorka & $\begin{array}{c}f_{\mathrm{cm}, \mathrm{pr}} \\
(\mathrm{MPa})\end{array}$ & $\begin{array}{c}f_{\text {cm,cu }} \\
(\mathrm{MPa})\end{array}$ & $\begin{array}{c}f_{\mathrm{cf}, \mathrm{m}} \\
(\mathrm{MPa})\end{array}$ & $\begin{array}{l}f_{\text {ct,sp,m }} \\
(\mathrm{MPa})\end{array}$ & $\begin{array}{c}E_{\mathrm{cm}} \\
(\mathrm{GPa})\end{array}$ & $\begin{array}{c}\rho_{\text {matrice }} \\
\left(\mathrm{kN} / \mathrm{m}^{3}\right)\end{array}$ \\
\hline SQ-7-200-0-1 & 17,96 & 19,31 & 4,57 & 2,48 & 19,719 & 22,550 \\
\hline SQ-7-200-40-S-4 & 17,96 & 19,31 & 4,57 & 2,48 & 19,719 & 23,027 \\
\hline SQ-7-200-40-S-5 & 17,96 & 19,31 & 4,57 & 2,48 & 19,719 & 22,955 \\
\hline SQ-7-200-40-S-8 & 17,74 & 18,55 & 4,49 & 2,40 & 18,077 & 22,560 \\
\hline SQ-7-200-40-S-13 & 18,74 & 21,43 & 3,95 & 3,28 & 17,746 & 22,998 \\
\hline SQ-7-200-40-S-10 & 17,74 & 18,55 & 4,49 & 2,40 & 18,077 & 22,762 \\
\hline SQ-7-200-40-S-11 & 18,74 & 21,43 & 3,95 & 3,28 & 17,746 & 22,370 \\
\hline SQ-7-200-40-S-14 & 18,74 & 21,43 & 3,95 & 3,28 & 17,746 & 22,861 \\
\hline SQ-7-200-40-S-16 & 18,74 & 21,43 & 3,95 & 3,28 & 17,746 & 23,032 \\
\hline SQ-7-200-40-S-17 & 18,34 & 20,14 & 4,01 & 3,13 & 18,579 & 22,801 \\
\hline SQ-7-150-0-1 & 19,02 & 20,33 & 4,04 & 3,34 & 17,409 & 22,276 \\
\hline SQ-7-150-30-S-4 & 18,12 & 20,27 & 4,34 & 3,04 & 16,510 & 22,113 \\
\hline SQ-7-150-30-S-5 & 18,12 & 20,27 & 4,34 & 3,04 & 16,510 & 22,397 \\
\hline SQ-7-150-30-S-8 & 15,09 & 16,73 & 3,80 & 2,69 & 16,762 & 22,072 \\
\hline SQ-7-150-30-S-13 & 18,02 & 21,27 & 4,26 & 3,05 & 19,168 & 22,419 \\
\hline SQ-7-150-30-S-10 & 15,09 & 16,73 & 3,80 & 2,69 & 16,762 & 22,137 \\
\hline SQ-7-150-30-S-11 & 15,09 & 16,73 & 3,80 & 2,69 & 16,762 & 22,500 \\
\hline SQ-7-150-30-S-14 & 18,02 & 21,27 & 4,26 & 3,05 & 19,168 & 22,603 \\
\hline SQ-7-150-30-S-16 & 18,02 & 21,27 & 4,26 & 3,05 & 19,168 & 22,088 \\
\hline SQ-7-150-30-S-17 & 18,02 & 21,27 & 4,26 & 3,05 & 19,168 & 22,706 \\
\hline SQ-7-100-0-1 & 18,34 & 20,14 & 4,01 & 3,13 & 18,579 & 22,880 \\
\hline SQ-7-100-20-S-4 & 18,34 & 20,14 & 4,01 & 3,13 & 18,579 & 22,501 \\
\hline SQ-7-100-20-S-5 & 18,34 & 20,14 & 4,01 & 3,13 & 18,579 & 22,583 \\
\hline SQ-7-100-20-S-8 & 19,02 & 20,33 & 4,04 & 3,34 & 17,409 & 22,480 \\
\hline SQ-7-100-20-S-13 & 11,39 & 12,53 & 2,49 & 1,83 & 14,597 & 22,331 \\
\hline SQ-7-100-20-S-10 & 19,02 & 20,33 & 4,04 & 3,34 & 17,409 & 22,524 \\
\hline SQ-7-100-20-S-11 & 19,02 & 20,33 & 4,04 & 3,34 & 17,409 & 22,922 \\
\hline SQ-7-100-20-S-14 & 11,39 & 12,53 & 2,49 & 1,83 & 14,597 & 22,502 \\
\hline SQ-7-100-20-S-16 & 11,39 & 12,53 & 2,49 & 1,83 & 14,597 & 22,149 \\
\hline SQ-7-100-20-S-17 & 11,39 & 12,53 & 2,49 & 1,83 & 14,597 & 22,549 \\
\hline
\end{tabular}




\section{Normovanie normovacieho parametra}

Rozdielne pevnostné charakteristiky betónu analyzovaných skúšobných vzoriek boli $\mathrm{v}$ rámci skúmania zohl'adnené normovaním skúmaných veličín pomocou normovacieho parametra. Normovací parameter musí byt' veličina/viaceré veličiny, ktoré najvýznamnejšie reflektujú rozdielnu kvalitu a vlastnosti betónu. Skúmané skúšobné vzorky sú namáhané osovým tlakom. Zohl’adnenie rozdielnej kvality betónu normovaním hranolovou/kockovou tlakovou pevnost'ou betónu je prvým predpokladom pri vol'be optimálneho parametra. Pri pôsobení osového tlaku je vznik trhlín (šmykových a tlakových) vo vzorkách jav, ktorý je možné vysvetlit’ vznikom trhlín v nepriamom t’ahu. Práve pevnostné charakteristiky betónu v t’ahu pri ohybe a v priečnom t’ahu by mohli vyriešit' vhodnú kombináciu rôznych materiálových vlastnosti skúšobných vzoriek pri meniacom sa počte inklúzií. Nakoniec medzi významné vlastnosti patrí objemová hmotnost’ betónovej matrice, ktorá vyjadruje kvalitu zhutnenie betónovej zmesi, čo môže vystihovat' mieru pravdepodobnosti výskytu vnútorných imperfekcií a ovplyvňovat' tak dosahovanú pevnost' skúšobných vzoriek. V Tab. 2 sú uvedené percentuálne rozdiely miery zhutnenia betónovej matrice na vzorkách troch rôznych sérií.

Tab. 2 Percentuálny rozdiel miery zhutnenia betónovej matrice.

\begin{tabular}{cc}
\hline Séria & $\Delta \boldsymbol{\rho}_{\text {matrice }}(\boldsymbol{\%})$ \\
\hline $200 \times 200 \times 50$ & 2,96 \\
$150 \times 150 \times 50$ & 2,87 \\
$100 \times 100 \times 50$ & 3,49 \\
\hline
\end{tabular}

Výber vhodnej kombinácie veličín do normovacieho parametra bol stanovený z variability rozdelenia nameraných hodnôt všetkých vzoriek prostredníctvom variačného koeficientu (Tab. 1).

Tab. 3 Hodnoty variačného koeficientu.

\begin{tabular}{ccccccc}
\hline Normovací parameter & $\boldsymbol{f}_{\text {cm,pr }}$ & $\boldsymbol{f}_{\text {cm,cu }}$ & $\boldsymbol{f}_{\text {cf,m }}$ & $\boldsymbol{f}_{\text {ct,sp,m }}$ & $\boldsymbol{E}_{\mathrm{cm}}$ & $\boldsymbol{\rho}_{\text {matrice }}$ \\
\hline Variačný koeficient & 12,42 & 12,74 & 13,19 & 15,79 & 7,63 & 1,27 \\
\hline
\end{tabular}

Z výpočtov sa javí ako najvhodnejšia kombinácia hranolovej pevnosti betónu v tlaku $\left(f_{\mathrm{cm}, \mathrm{pr}}\right)$ a pevnosti betónu $\mathrm{v}$ t’ahu pri ohybe $\left(f_{\mathrm{cf}, \mathrm{m}}\right)$. Táto kombinácia bola vyjadrená geometrickým priemerom oboch hodnôt a zohl'adnením príslušnej miery zhutnenia každej skúšobnej vzorky. Normovanie veličín bolo dosiahnuté pomerom kontaktného tlakového napätia v príslušnom zat’ažovacom kroku a normovacieho parametra (1).

$$
\sigma /\left(f_{c m, p r} \cdot f_{c f, m}\right)^{1 / 2} \cdot \rho_{\text {matrice }}
$$

\section{VÝSLEDKY A DISKUSIA}

Výsledky analýzy sú prezentované na troch grafoch závislosti kontaktné tlakové napätie/normovací parameter $u / u_{\text {peak }}$. Rozdielne hodnoty normovanej pevnosti skúšobných vzoriek boli analyzované vzhl'adom na jednotkovú vodorovnú os, čo umožnilo prehl'adnejšie porovnanie dosahovaných napätí. Na Obr. 2 sú znázornené výsledky skúšobných vzoriek s rozmermi $200 \times 200 \times 50 \mathrm{~mm}$, kde sa menil počet inklúzií od 1 do 4 vzhl'adom na ich asymetrické usporiadanie v smere pôsobenia zat’aženia. Zároveň, každá skúšobná séria obsahovala vzorku bez inklúzie s ciel’om určit' vzt'ažnú hodnotu pri analýze porovnávaných medzných napätí vzoriek s inklúziami. Obdobne bola vykonaná analýza medzných napätí na sérí́ vzoriek s rozmermi $150 \times 150 \times 50 \mathrm{~mm}(\mathrm{Obr}$. 3), a nakoniec na vzorkách s rozmermi $100 \times 100 \times 50 \mathrm{~mm}$ (Obr. 4).

Z výsledkov experimentálnych skúšok sa zistilo, že rozsah nameraných hodnôt medzných napätí sa výraznejšie znížil na vzorkách najmenších rozmerov, teda pri poklese štíhlosti skúšobných vzoriek. Zatial' čo pri vzorkách s rozmermi $200 \times 200 \times 50 \mathrm{~mm}(h / d=4,0)$ bol percentuálny rozdiel medzného napätia celej série $27,1 \%$, tak pri vzorkách s rozmermi $150 \times 150 \times 50 \mathrm{~mm}(h / d=3,0)$ bola zaznamenaná zmena o hodnote $27,2 \%$ a nakoniec pri vzorkách s rozmermi $100 \times 100 \times 50 \mathrm{~mm}(h / d=2,0)$ o hodnote $13,4 \%$.

Pri analýze celého súboru vzoriek bolo zaznamenané v prvotných fázach zat’aženia takmer lineárne pružné správanie vzostupnej vetvy krivky. Jej čiastočne zakrivenie a nelineárny charakter nastal v dôsledku prítomnosti inklúzií v betónovej matrici, pričom na ich rozhraní vznikali počiatočné trhliny. Ďalší nárast tlakového napätia zvýšil množstvo a dížku trhlín, čo sprevádzalo väčšie zakrivenie vzostupnej vetvy až do nadobudnutia medznej pevnosti. V neskorších štádiách zat’ažovania nastalo väčšie zoskupenie trhlín a ich rast sa stal nestabilným. Pri nadobudnutí medzného napätia bola dosiahnutá kritická dĺžka a hustota trhlín, čo spôsobilo porušenie vzorky. 


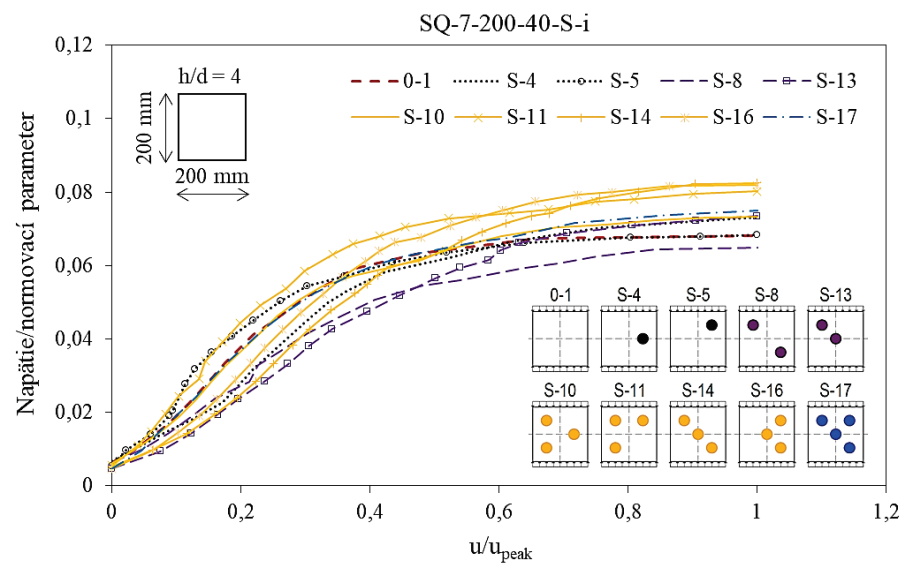

Obr. 2 Graf závislosti normovanej pevnosti betónu a pomeru $u / u_{\text {peak }}$ vzoriek s rozmermi $200 \times 200 \times 50 \mathrm{~mm}$.

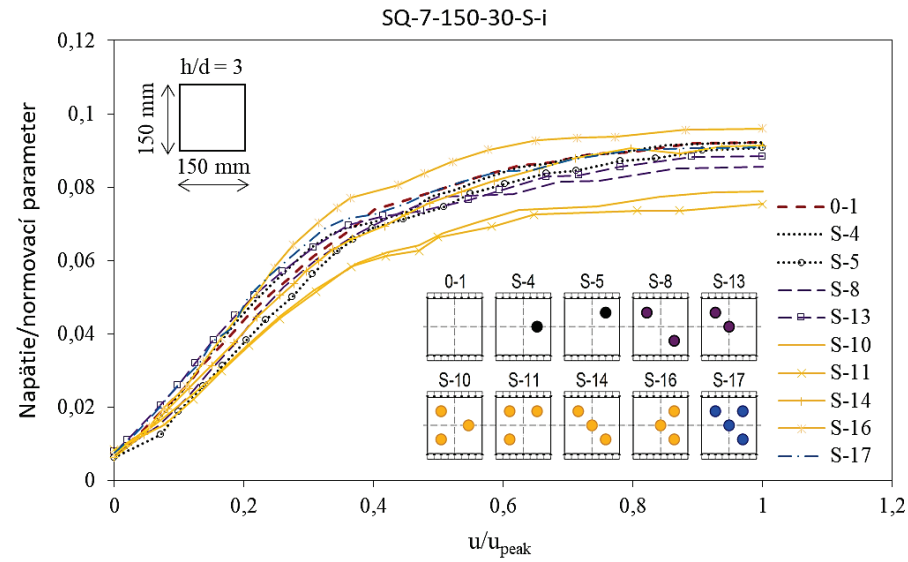

Obr. 3 Graf závislosti normovanej pevnosti betónu a pomeru $u / u_{\text {peak }}$ vzoriek s rozmermi $200 \times 200 \times 50 \mathrm{~mm}$.

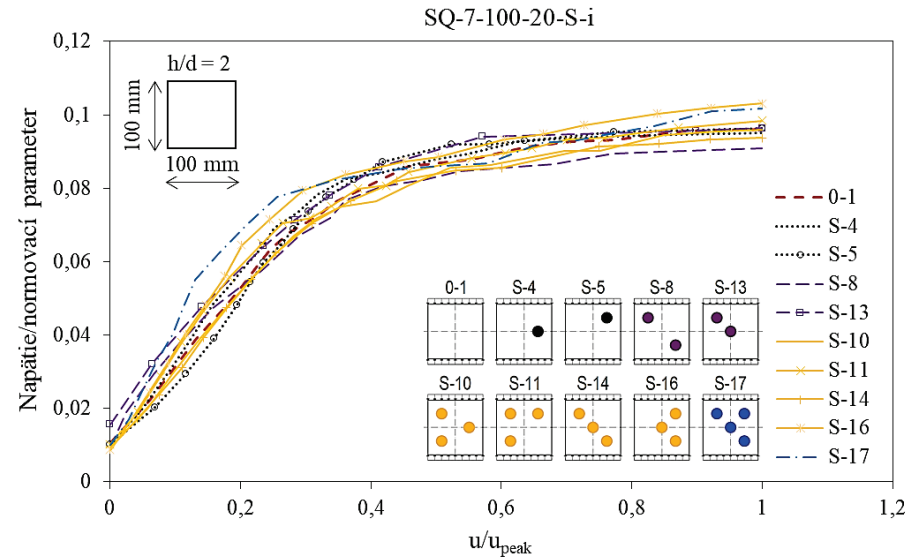

Obr. 4 Graf závislosti normovanej pevnosti betónu a pomeru $u / u_{\text {peak }}$ vzoriek s rozmermi $200 \times 200 \times 50 \mathrm{~mm}$. 
Na Obr. 5 je uvedená súhrnná analýza nameranej normovanej pevnosti skúšobných vzoriek. Jej vyhodnotenie na troch rôznych vel'kostiach skúšobných vzoriek nepreukázalo jasne definovaný vzájomný vzt’ah medzi počtom inklúzií a nameranou normovanou pevnost'ou, čo je v protiklade z predchádzajúcimi zisteniami [5]. Z výsledkov experimentov je možné konštatovat', že nárast počtu inklúzií z 1 na 4 zvýšil normovanú pevnost' telies pri vzorkách s rozmermi $200 \times 200 \times 50 \mathrm{~mm}$ (s výnimkou vzorky $S$-8), zatial' čo pre vzorky s rozmermi $150 \times 150 \times 50 \mathrm{~mm}$ a $100 \times 100 \times 50 \mathrm{~mm}$ toto tvrdenie nemožno uplatnit'. Zároveň je možné všeobecne uviest', že nameraná normovaná pevnost' skúšobných vzoriek sa zvýšila pri zmenšení rozmeru skúšobnej vzorky, resp. pri poklese štíhlosti.

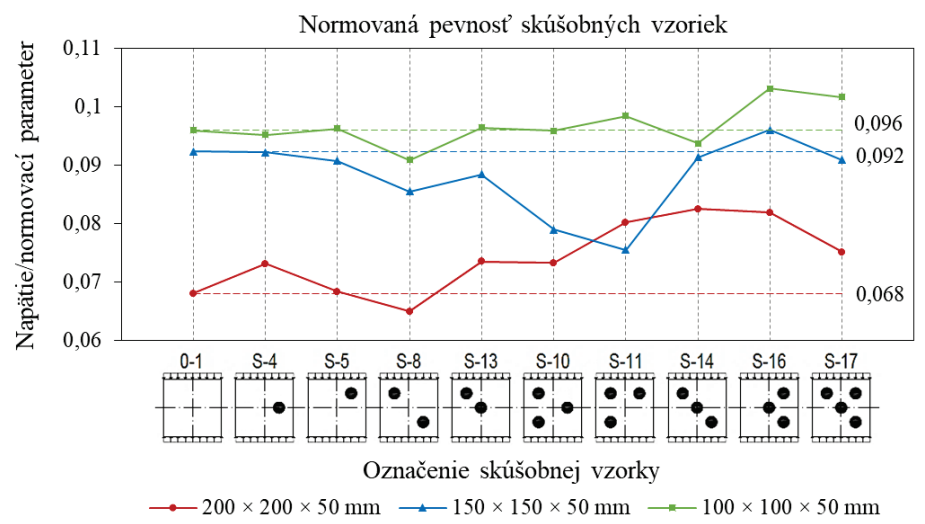

Obr. 5 Graf závislosti normovanej pevnosti skúšobných vzoriek pri zmene ich vel'kosti.

\section{ZÁVER}

Na základe sérií vykonaných experimentálnych skúšok možno konštatovat', že vplyv počtu asymetricky usporiadaných inklúzií závisel od vel'kosti skúšobných telies pri ich meniacej sa štíhlosti. Zistilo sa, že účinok rozdielneho počtu inklúzií sa najviac prejavil na vzorkách s rozmermi $200 \times 200 \times 50 \mathrm{~mm}$ a $150 \times 150 \times 50 \mathrm{~mm}$, pričom pri zmenšení vel'kosti vzoriek na $100 \times 100 \times 50 \mathrm{~mm}$ sa tento rozsah znížil. Tento jav môže byt' vysvetlený relatívnou zmenou objemu inklúzií vzhl'adom na meniacu sa vel'kost' skúšobnej vzorky. Na druhej strane, zmena vel'kosti inklúzií ovplyvnila plochu rozhrania. Vplyv slabého rozhrania (počet, vel'kost') tak mohla negatívne ovplyvňovat' dosahovanú pevnost' skúšobných vzoriek vzhl'adom na prítomnost' tuhej inklúzie v relatívne mäkkej matrici. Ďalej sa zistilo, že medzi vzorkou bez inklúzie a vzorkami s meniacim sa počtom inklúzií nebola preukázaná korelácia nameraných hodnôt medzného napätia. Tento problém sa môže vyriešit' opakovaním experimentu a kvantifikáciou výsledkov, alebo porovnaním výsledkov experimentu s numerickým modelom.

\section{Pod'akovanie}

Túto prácu podporila Slovenská vedecká grantová agentúra na základe zmluvy č. VEGA 1/0363/21.

\section{Použité zdroje}

[1] BILČÍK, Juraj a Ludovít FILLO. Betónové konštrukcie: Konštruovanie pomocou prútových modelov. Bratislava: STU v Bratislave, 1997, 110 s. ISBN: 80-227-0922-0.

[2] VONK, R. A. Softening of concrete loaded in compression. PhD Thesis. Netherlands: Eindhoven University of Technology, 1992, $192 \mathrm{~s}$.

[3] VAN MIER, J. G. M. Failure of concrete under uniaxial compression: An overview. In: $3^{\text {nd }}$ Int. Conf. on Fracture Mechanics of Concrete and Concrete Structures (FraMCoS-3). Freiburg, 1998, s. 1169-82.

[4] VERVUURT, A. a J. G. M. VAN MIER. Interface fracture in cement-based materials. In: Proc. $2^{\text {nd }}$ Int. Conf. on Fracture Mechanics of Concrete and Concrete Structures (FraMCoS-2). Freiburg, 1995, s. 295-304.

[5] CHOI, S. Nondestructive evaluation of cement-based materials with computer vision. In: $3^{\text {nd }}$ Int. Conf. on Fracture Mechanics of Concrete and Concrete Structures (FraMCoS-3). Freiburg, 1998, s. 17-24.

[6] KOVÁČ, Maroš. Compressive strength of concrete specimens with inclusions. In: IOP Conference Series: Materials Science and Engineering. 867. IOP Publishing, 2020, 8 s. 